\title{
ON THE IMPORTANCE OF THE ESTONIAN CONSTITUTIONAL TYPING SYSTEM FOR SPORTS ANTHROPOLOGY
}

\author{
CHRISTOPH RASCHKA
}

Institute of Sports Science, Julius Maximilian University of Würzburg, Germany

\begin{abstract}
In sports anthropology, two main international schools of constitutional typing are used: on the one hand the Anglo-American tradition of somatotyping, but in the German-speaking world, on the other hand, the checkerboardtype constitution type system (Conrad) has dominated. A unique innovative approach to determining the individual constitutional type was achieved by Helje Kaarma: the Estonian constitutional typing system, consisting of the 5 height-weight class system (small, medium, large, pyknomorphic and leptomorphic). In a series of follow-up studies, Kaarma and her daughter R. Stamm succeeded in establishing this system in sports anthropology. Furthermore, Papers on Anthropology is an important scientific platform for international sports anthropological research.
\end{abstract}

Keywords: sports anthropology; somatotyping; checkerboard-constitutional typing system; Estonian constitutional typing system; Helje Kaarma; Papers on Anthropology

Sports anthropology as comparative biology of sportsmen and sportswomen deals with the constitution types (somatotypes), the body composition and the proportions of the athletes but also with other anthropological issues [36, 45, $46]$, such as the evolution of the musculoskeletal system or the cardiovascular system $[30,60]$.

Sport anthropometry as a key method aims at the metric capture of the morphological features relevant for sports [30].

The corresponding international term 'kinanthropometry' is defined as the study of human size, shape, proportions, composition, maturation, and gross 
function, in order to understand growth, exercise, performance, and nutrition. Kinanthropometry is the interface between human anatomy and movement [30].

From the very beginning [2], sports anthropology, in addition to the very developed industrial anthropology, was one of the few areas of "applied anthropology". Primarily, this discipline devoted itself to trying to find the most suitable constitutional type for each sport [24].

So, the constitutional types of the most important anthropological schools were used for sports anthropology. In principle, one can distinguish two main international schools of constitutional typing: on the one hand, the AngloAmerican tradition, based on the famous somatotyping of Sheldon [51] with the anthropometrically based continuations of Parnell $[27,28]$ and Heath \& Carter [12].

On the other hand, in the German-speaking world, initially in the territory of the former GDR, propagated by Tittel and Wutscherk [60-62], later in the whole of Germany $[1,6-11,30,49,50]$ the checkerboard-type constitution type system of Conrad dominated $[3,4]$.

The determinant for the expression of the lepto- or pyknomorphic direction is the Strömgren index (metric index). The plastic index introduced by Conrad serves to determine the hypo- or hyperplastic degree of body development $[3,4]$.

The Mainz School of Anthropology uses the Cartesian coordinate system of Knussmann $[18,19]$ with a leptomorphic-pycnomorphic variation vs. a macrosome-microsome variation. This determination system was also used by the sports anthropologists in Frankfurt/Main and Würzburg [5-11, 17, 20, 25, 26, 30-35, 37-44, 47-50].

A unique innovative approach to determining the individual constitutional type was achieved by Helje Kaarma. While the somatotyping of the AngloAmericans (Sheldon, Parnell, Heath \& Carter) was based on a three-pole type system, and the German constitution typifications (Conrad's chessboard pattern und Knussmann's Cartesian model) was based on a four-polar type system, Kaarma and co-workers chose a highly innovative new approach: the Estonian constitutional typing system, consisting of five height-weight classes [13-16, 21-23, 29]. There were three classes with harmony between height and weight class: 1 - small (small height and small weight), 2 - medium (medium height and medium weight), 3 - large (large height and large weight), 4 - weight class dominating (pycnomorphic) and 5 - height class dominating (leptomorphic).

In a series of follow-up studies, Kaarma and her daughter R. Stamm also succeeded in establishing the Estonian constitution type system in the field 
of sports anthropology (for example volleyball players) and sports science [52-59].

The innovative significance of this work lies in the integration of sports anthropometric and training science parameters in a test battery for the prediction of volleyball performance level.

Kaarma has rightly secured a place in the ranks of the great physique researchers and sports anthropologists with her intelligent new constitutional system. Also, her journal Papers on Anthropology is a wonderful scientific platform for the publication of international sport-anthropological research $[5,10$, $17,20,25,26,31-34,38,39,41-44,47,48,52,53,55-57]$.

I cordially congratulate my esteemed colleague Helje Kaarma on her outstanding scientific achievement on the occasion of the current anniversary the Centre for Physical Anthropology at the Medical Faculty and at the Institute of Anatomy of University of Tartu has become 25 years old!

\section{REFERENCES}

1. Anders M., Raschka C. (2006). Konstitutionstypen heranwachsender Karateka und Judoka im Vergleich. Beiträge zur Archäozoologie und Prähistorischen Anthropologie; Band V: 219-24. Verlag Beier \& Beran.

2. Bach F. (1930). Leitfaden zu anthropometrischen Sporttypenuntersuchungen und deren statistischer Auswertung. München: Verlag der Ärztlichen Rundschau, Otto Gmelin.

3. Conrad K. (1941). Der Konstitutionstypus als genetisches Problem. Berlin: Springer-Verlag.

4. Conrad, K. (1963). Der Konstitutionstypus. Berlin, Göttingen, Heidelberg: Springer-Verlag,

5. Dogan C., Raschka C. (2011). Anthropometrical and sport constitutional comparison of German male soccer players and male students of sport sciences. Papers on Anthropology, XX, 78-92.

6. Drescher M, Raschka C. (2009). Sportanthropometrischer und konstitutionsbiologischer Vergleich von BadmintonspielerInnen aus drei verschiedenen Leistungsbereichen. Deutsche Zeitschrift für Sportmedizin, 60 (7-8), 240

7. Fritzsche J., Raschka C. (2006a). Sportanthropologische Untersuchungen der aktiven, passiven und gesamten Körpermasse von Elitekarateka (Sports anthropological investigations on active, passive and whole body mass of elite karateka). Österreichisches Journal für Sportmedizin, 36 (2/3), 33-40.

8. Fritzsche J., Raschka C. (2006b). Sportanthropologische Untersuchungen an Elite-Karateka unter besonderer Berücksichtigung der deutschen und 
angelsächsischen Konstitutionstypologien. Beiträge zur Archäozoologie und Prähistorischen Anthropologie, Band V, 225-230. Verlag Beier \& Beran.

9. Fritzsche J., Raschka C. (2007). Sportanthropologische Untersuchungen zur Konstitutionstypologie von Elitekarateka. Anthropol Anz, 65(3), 317-29.

10. Fritzsche J, Raschka C. (2008). Body composition and the somatotype of German top Taekwondo practitioners. Papers on Anthropology XVII, 58-71.

11. Fritzsche J., Raschka C., Heller C. (2008). Vergleichende konstitutionstypologische Untersuchungen von deutschen Top Taekwondoka und Karateka. Österr J Sportmed, 38 (3/4), 17-24.

12. Heath B. H., Carter J. E. L. (1967). A modified somatotype method. Am J Physic Anthropol, 27, 57-74.

13. Kaarma H., Stamm R., Kasmel J., Koskel S. (2005). Body build classification for ordinary schoolgirls (aged 7-18 years) and volleyball girls (aged 13-16 years). Anthropol Anz, 63(1), 77-92.

14. Kaarma H., Veldre G., Saluste L., Lintsi M., Kasmel J., Tiit E.-M., Stamm R., Toomsalu M., Arend A. (2017). On systematization of Estonians' body build data. Papers on Anthropology XXVI/1, 9-27.

15. Kaarma H., Veldre G., Stamm R., Lintsi M., Kasmel J., Maiste E., Koskel S. (2001). Regularities of body build structure of Estonian girls and youths. Morfologiya (in Russian), 120 (6), 80-82.

16. Kasmel J., Kaarma H., Koskel S., Tiit E.-M. (2004). Body build classes as a method for systematization of age-related anthropometric changes in girls aged 7-8 and 17-18 years. Anthropol Anz, 62(1), 93-106.

17. Kleinwächter R., Raschka C. (2009). Anthropometrical and sport-constitutional comparison of male and female tennis players at different performance levels. Papers on Anthropology, XVIII, 214-226.

18. Knußmann R. (1961a) Zur Methode der objektiven Körperbautypognose. Z. menschl. Vererb. u. Konst.-Lehre 36, 1-44.

19. Knußmann R. (1961b) Makrosomie-Mikrosomie als körperbautypologische Variationsreihe II. Ordnung. Homo 12, 1-16.

20. Krick C., Raschka C. (2012). Sports anthropological comparison between male martial arts fighters and the students majoring in physical education. Papers on Anthropology, XXI, 155-162.

21. Lintsi M., Kaarma H. (2003). Five-class height-weight model for systematization of seventeen-year-old recruits' anthropometric data. Anthropol Anz, 61(4), 435-443.

22. Lintsi M., Kaarma H., Aunapuu M., Arend A. (2007). Five-class height-weight mean and SD system applying Estonian reference values of height-weight mean and SD for systematization of seventeen-year-old conscripts' anthropometric data. Anthropol Anz. 65(1), 37-49.

23. Lintsi M., Kaarma H., Saluste L., Vasar V. (2002). Systemic changes in body structure of 17-18-year-old schoolboys. Homo, 53(2), 157-69. 
24. Martin R., Knußmann R. (eds.) (1988). Anthropologie. Handbuch der vergleichenden Biologie des Menschen. Band I/1. Wissenschaftstheorie, Geschichte, morphologische Methoden. Stuttgart, New York: Gustav Fischer Verlag.

25. Matyk M., Raschka C. (2011). Body composition and the somatotype of European top roller speed skaters. Papers on Anthropology XX, 258-271.

26. Mikhailov V., Raschka C. (2010). Anthropometrical and sport-constitutional comparison of male and female ballroom- and Latin-dancers with regard to different performance levels. Papers on Anthropology XIX, 258-270.

27. Parnell R. W. (1954). Somatotyping by physical anthropometry. Am J Phys Anthrop, 12, 209-239.

28. Parnell R. W. (1958). Behaviour and physique. London: Arnold.

29. Peterson J., Kaarma H., Koskel S. (2007). Using a height-weight classification for analysis of food energy and main nutrient contents in 24-hours menus of 17-23-year-old Estonian female students. Anthropol Anz, 65(1), 51-59.

30. Raschka C. (2006). Sportanthropologie. Leitfaden der modernen, vergleichenden Sportanthropologie, Sportanthropometrie und trainingsrelevanten Konstitutionsbiologie. 1. Auflage. 342 S. Sportverlag Strauß.

31. Raschka C., Aichele S. K. (2014). Correlations between somatotypes and nutritional intake in sports students. Papers on Anthropology XXIII/2, 96-104.

32. Raschka C., Bambusek D., Türk J. (2012). Anthropometrical and sport constitutional comparison between young firefighters ( $\leq 30$ years) and sport students ( $\leq 30$ years). Papers on Anthropology XXI, 246-255.

33. Raschka C., Bauer C. (2014). Sports anthropological study of somatotypical changes in obese patients during a two-week inpatient rehabilitation program. Papers on Anthropology XXIII/2, 79-83.

34. Raschka C.; Beyer K. (2015). Sports anthropological and somatotypical investigation of male and female Latin dancers. Papers on Anthropology XXIV/2, 94-101.

35. Raschka C., Bouzommita S., Preiß R. (2005). Sportanthropologische Analyse tunesischer Spitzenkarateka. (Sports-anthropological analysis of Tunisian elite karateka). Anthropol Anz, 63(4), 415-426.

36. Raschka C., Flohr St. (2006). Leistungsphysiologische Aspekte zur Morphologie des Torus supraorbitalis. Beiträge zur Archäozoologie und Prähistorischen Anthropologie, Band V, 136-142. Verlag Beier \& Beran.

37. Raschka C., Fröhlich G. (2006). Konstitutionstypen männlicher und weiblicher Ju-Jutsu-Wettkämpfer.(Somatotypes of male and female competitive Ju-Jutsuka). Anthropol Anz, 64(4), 435-446.

38. Raschka C.; Graczyk,J. (2013). Correlations between somatotypes and nutritional intake in members of a fitness studio. Papers on Anthropology XXII, 145-152. 
39. Raschka C., Heppenheimer, V. (2016). Sports anthropological and somatotypical comparison between female wrestlers and hapkidoin of different performance levels. Papers on Anthropology XXV/2, 43-54.

40. Raschka C., Jakob Th., Preiß R. (2012). Sportanthropometrische Untersuchung deutscher Rugbyspieler. In: Haase H, Krüger F, Nicol K, Preiß R (Hrsg.): Leistungsdiagnostik und Trainingssteuerung (zur Erinnerung an Rainer Ballreich), S. 247-254. Köln: Sportverlag Strauß.

41. Raschka C., Kassühlke, A., Ifland,C. (2014). Sports anthropological and somatotypical investigation of female handball players of different performance classes. Papers on Anthropology XXIII/2, 84-95.

42. Raschka C., Kothe P. (2012). Sports anthropological comparison of physically exercising patients with Diabetes Type I and Diabetes Type II. Papers on Anthropology XXI, 256-263.

43. Raschka C., Müller J. (2017). Sports anthropological and somatotypical comparison between male wrestlers and hapkidoin of different performance levels. Papers on Anthropology XXVI/1, 52-63.

44. Raschka C., Müller Th., Ludwig A. (2013). Sports anthropological investigation of male basketball players of different performance classes. Papers on Anthropology XXII, 162-170.

45. Raschka S., Raschka C. (2008). Über die Beziehung zwischen Körperbau und Appendixlänge. Anthropol Anz, 66(1), 67-72.

46. Raschka C., Schiller S. (2014). Entwicklungsgeschichte der Menschen. Eine kurze Einführung in die Paläoanthropologie. 1. Auflage. 43 S. Göttingen: Planet Poster Editions.

47. Raschka C., Schmidt K. (2013). Sports anthropological and somatotypical comparison between higher class male and female badminton and tennis players. Papers on Anthropology XXII, 153-161.

48. Raschka C., Vöth K., Kuczera K. (2015). Sports anthropological and somatotypical comparison between young male shotputters and javelin throwers of different performance classes and recreational athletes. Papers on Anthropology XXIV/2, 129-141.

49. Raschka C., Wolthausen C. (2007). Vergleich körperbautypologischer Unterschiede bei Fußball- und Handballspielern mit Methoden deutscher und angloamerikanischer Konstitutionsschulen. Anthropol Anz, 65(3), 303-316.

50. Raschka C., Zanellato S. (2003). Sportanthropologische Untersuchung von Teilnehmerinnen der Deutschen Sport-Aerobic-Meisterschaft im Vergleich zu Sportstudentinnen und Sport treibenden jungen Frauen. Anthropol Anz, 61(4), 461-472.

51. Sheldon,W. H. (1940). The varieties of human physique. New York, London: Harper. 
52. Stamm R., Stamm M., Jairus A., Toop R., Tuula R., Joao P. V. (2017). Do height and weight play an important role in block and attack efficiency in high levels men's volleyball? Papers on Anthropology XXVI/1, 64-71.

53. Stamm R., Stamm, M., Koskel, S. (2002). Age, body build, physical ability, volleyball technical and psychophysiological tests and proficiency at competition in young female volleyballers (aged 13-16 years). Papers on Anthropology XI, 253-282.

54. Stamm R., Stamm M., Oja A. (2000). A system for recording volleyball games and their analysis. Int J Volleyball Res, 2 (1), 18-22.

55. Stamm R., Stamm M., Torilo K., Thomson K., Jairus A. (2016). Comparative analysis of the elements of the attack and defence in men's and women's games in the Estonian volleyball highest league. Papers on Anthropology XXV/1, 37-54.

56. Stamm R., Stamm M., Pähn M., Jairus A. (2015). Comparison of the body build and physical abilities of the students of sports classes and ordinary classes. Papers on Anthropology XXIV/2, 102-113.

57. Stamm R., Stamm M., Vantis M., Jairus A. (2016). Comparative analysis of serve and serve reception performance in pool B of European Men's Volleyball Championship 2015. Papers on Anthropology XXV/2, 55-69.

58. Stamm R., Veldre G., Stamm M., Kaarma H., Koskel S. (2001). Young female volleyball players' anthropometric characteristics and volleyball proficiency. Int J Volleyball Res, 4 (1), 8-11.

59. Stamm R., Veldre G., Stamm M., Thomson K., Kaarma H., Loko J., Koskel S. (2003). Dependence of young female volleyballers' performance on their body build, physical abilities, and psycho-physiological properties. J Sports Med Phys Fitness, 43, 431-439

60. Tittel K., Wutscherk H. (1972). Sportanthropometrie. Leipzig: Barth.

61. Tittel K., Wutscherk H. (1974). Anthropometrische Meßverfahren zur Bestimmung der Beziehungen zwischen Körperbaumerkmalen und sportlicher Leistungsfähigkeit. Theorie und Praxis der Körperkultur, 23, 171.

62. Tittel K., Wutscherk H. (1978). Vorzüge und Grenzen der Conradschen Methode in der Sportanthropometrie. Med. u. Sport, 18, 11.

\section{Address for correspondence:}

Prof. Dr.med. Dr.rer.nat. Dr.Sportwiss. Christoph Raschka Institute of Sports Sciences, Julius-Maximilians-University, Germany Judenbühlweg 11

D-97082 Würzburg

E-mail: christoph.raschka@uni-wuerzburg.de 